\title{
Form-focused Instruction: A New Interpretation of TBLT in Iranian EFL Setting
}

\author{
Mojgan Rashtchi \\ Department of TEFLL, North Tehran Branch, Islamic Azad University, Tehran, Iran \\ Email: mojgan.rashtchi@gmail.com \\ Arshya Keyvanfar \\ Department of TEFLL, North Tehran Branch, Islamic Azad University, Tehran, Iran \\ Email: arshyak@yahoo.com
}

\begin{abstract}
Task-based language teaching (TBLT) with its emphasis on the application of meaningful tasks seemingly undermines the importance of teaching language forms to the extent that many teachers and learners around the globe have come to believe that TBLT is the easy way out of the maze of English language learning. Nevertheless, a close inspection of the practical aspects of the approach may prove otherwise. The researchers of the present study have investigated the applicability of TBLT in the Iranian setting where English is taught as a foreign language (EFL). In so doing, a 15-item questionnaire with two versions for EFL learners and teachers was developed in Farsi by the researchers based on the one used by Schulz (2001). It was administered to 145 learners and 36 teachers in a language school in Tehran, Iran. Based on the findings it could be concluded that ELT in Iran is not fully compatible with TBLT and form-focused instruction which includes both Focus on Form as well as Focus on FormS is more promising in the EFL setting of Iran.
\end{abstract}

Index Terms - form-focused instruction, Iranian EFL setting, real-life tasks, TBLT

\section{INTRODUCTION}

Task-based language teaching has been very well received in the majority of English language teaching circles in Iran. The abundance of task-based materials on the one hand and the increasing dominance of high stakes task-based examinations such as IELTS have accelerated this shift of paradigm. Nevertheless, the over-enthusiasm of ELT policy makers in Iran has prevented them to realize that the full implementation of TBLT requires certain preconditions which may be precarious if not completely absent in a country like Iran where learning and teaching grammar remains to be a major hurdle. The present study aims at elucidating the inevitability of a form-focused version of TBLT in the Iranian EFL setting.

A close look at the history of language teaching reveals that almost all methods after Grammar Translation Method have been after the development of communication ability in learners. It was not until the late 1970s that scholars such as Wilkins, Widdowson, Candlin, and Brumfit attempted to devise a framework for a communicative approach to language teaching. Communicative Language Teaching (CLT), the result of the shift of paradigm from a linguistic perspective to a communicative one, became widespread during 1970s and early 1980s. CLT brought about the idea that the best way for language learning is communication and actual involvement in language interactions. It presented the PPP model (presentation, practice, production) where students master "the target language in ready-to-assimilate pieces" (Foster, 1999). The CLT movement developed into TBLT because tasks were considered to be useful means for applying the principles of CLT. In other words, tasks were chosen to convert the theoretical principles of CLT into practice.

In task-based language teaching and learning, the learning activities focus on the meaningful use of language within a social setting. The classroom teaching and learning activities are organized around tasks instead of around language items. The assumption is that by engaging learners in a task, they would be able to learn the structure of the language in a more natural and meaningful way, while task completion can bring about many opportunities for the learners to interact with others (Larsen-Freeman, 2000). In this way, learners benefit not only from comprehensible input proposed by Krashen $(1981 ; 1985 ; 1994)$ but also from the opportunities to negotiate meaning and engage in naturalistic and meaningful communication referred to by Swain as comprehensible output hypothesis and by Long as interaction hypothesis (Swain, 1985; Long, 1996).

Tasks are defined as activities performed by learners through which they use the target language for a communicative purpose in order to achieve an outcome. Prabhu (1987) stated that a task "is an activity that requires learners to arrive at an outcome from given information through some process of thought, and which allows teachers to control and regulate that process" (p. 17). Breen (1987) views language tasks as a range of work plans, from simple to complex that learners use to communicate meaning. To Breen, "all materials for language teaching ... can be seen as compendia of tasks" (p. 26). Skehan's (1998) comprehensive account of the nature of a task refers to a task as a meaningful activity with 
communicative intentions which involves real-life like activities similar to those learners may encounter outside the classroom environment.

Nunan (2006), on the other hand, asserts that learners try to activate their grammatical knowledge in performing a task to express meaning rather than to manipulate form. Moreover, he adds that completing a task requires learners to focus on meaning rather than on form although form is considered to be an important factor in task completion. The extent to which form has been emphasized over meaning is well demonstrated in Long's (1996) interpretation of task goals and includes Focus on FormS, Focus on Meaning, and Focus on Form.

Wilkins's classification of syllabi, however, comes useful when discussing the conflict between form and meaning. Wilkins (1976) classifies syllabi into analytic and synthetic. The former refers to those syllabi which introduce language in holistic chunks and thus learners are expected to analyze and break them into parts. The latter, conversely, introduces language in discrete lists of items requiring learners to synthesize and put together the elements of language for use in communication, leading to a step by step acquisition of gradual accumulation of parts until the whole structure of language has been built up.

Doughty and Williams (1998) asserted that the traditional notion of forms always entails isolation or extraction of linguistic features from context or from communicative activity. As Long and Robinson (1998) contended, "Synthetic syllabi, together with the corresponding materials, methodology, and classroom pedagogy lead to lessons with a Focus on Forms" (p. 16). In synthetic syllabi, pedagogical material and accompanying classroom procedures are designed to present and practice a series of linguistic items, or forms. Synthetic syllabi (such as lexical, structural, and notional functional), as Long (1997) mentions, are accompanied by synthetic methods (Grammar Translation and Audio Lingual Method, for example). Long (1997) indicates several problems existent with Focus on FormS. As he maintains, Focus on FormS lacks needs analysis to identify the communicative needs of a particular group of learners, and there is no means analysis to ascertain their learning styles and preferences; thus, as he argues, it is a one-size-fits-all approach. Furthermore, as he puts forward, linguistic grading, both lexical and grammatical, tends to result in pedagogic materials which are essentially artificial and functionally restricted or what may be called language usage rather than language use. Finally, leaving learners out of syllabus design ignores the major role they will play in language development; that is, the internal syllabus of learners is ignored.

A typical response to frustration with Focus on FormS has been a radical pendulum swing: a shift of allegiance to an equally single minded focus on meaning (Long, 1997). These kinds of lessons with a Focus on Meaning are purely communicative. In Focus on Meaning approach, classroom work is wholly concerned with communication of meaning, with no attention given to the forms used to convey the message. The Natural Approach of Krashen and Terrell (1983) and other non-interventionist approaches are examples of this position.

Wilkins (1976) termed the language teaching syllabi of Focus on Meaning as analytic. "Analytic approaches are organized in terms of the purposes for which people are learning language and the kinds of language performance that are necessary to meet those purposes (p. 18)." As Long (1997) mentioned, in analytic syllabi, learners are presented with comprehensible samples of communicative second language use and it is the learner, not the teacher or textbook writer, who must analyze the L2, at a subconscious level, and induce grammar rules simply from exposure to the input, that is from positive evidence alone. The assumption is that grammar is best learned incidentally and implicitly. According to this view, L2 acquisition is essentially similar to L1 acquisition.

According to Izumi (2002), the major support for the communicative approach comes from immersion education in which the focus is on meaning through subject matter instruction and the provision of rich, comprehensible input. However, the evaluation of the immersion program in Canada in addition to some other content-based courses revealed that although learners develop excellent comprehension skills and fluency, their productive skills lack native like accuracy. The language developed is characterized by fossilization or classroom pidgin as a result of learners' trying to communicate freely beyond their limited linguistic competence. Moreover, unlearnability of some L1- L2 grammatical contrasts requires either the enhancement of positive evidence or the provision of negative evidence of some kind.

In spite of this, Focus on Form has received considerable attention in late decades as theorists and researchers have called for an integration of meaning-focused and form-focused instruction in the L2 educational settings. As defined by Richards and Schmidt (2002), Focus on Form in a technical sense is a brief allocation of attention to linguistic form as the need for this arises incidentally in the context of communication. This may be contrasted with a Focus on Form S (plural), referring to the kind of focus on form (or rule) where there is a 'structure of the day', usually pre-specified by the teacher or textbook. Unlike the synthetic approach of Focus on FormS to language, where the primary focus of classroom activity is on language forms rather than the meanings they convey, Focus on Form consists of an occasional shift of attention to linguistic code features by the teacher or one or more students (Long \& Robinson, 1998). In this way, the learners' attention is drawn precisely to a linguistic feature that is necessitated by a communicative demand.

In fact, Focus on Form has developed as a reaction against a communicative approach which advocates the exclusive use of meaning-focused activities in language classrooms. As Nassaji (1999) pointed out, indeed, with the introduction of the communicative approach in second language teaching and learning, there appeared a strong tendency not to focus on linguistic forms and consequent downplaying of the status of grammar teaching. Yet, the perspectives on language teaching and learning have changed dramatically. New perspectives advocate a principled Focus on Form approach to L2 learning arguing that approaches which are entirely based on some content knowledge are inadequate for the 
development of accuracy in language (Nassaji, 1999). According to Long (1997), Focus on Meaning alone is insufficient to achieve full native-like competence and can be improved upon, in terms of both rate and ultimate attainment, by periodic attention to language forms as object. There are three fundamental assumptions behind Focus on Form instruction. The first assumption is that meaning and use must already be evident to the learner at the time that attention is drawn to the linguistic apparatus needed to get the meaning across; second if learners need a form that they realize they do not know or fully control, this may increase the salience, and consequently, noticing of that form, and the last assumption is that negative feedback obtained in negotiation work or elsewhere may be facilitative of SL development, at least for learning certain L1-L2 contrasts.

In short, as Poole (2005) puts it, Focus on Form instruction is a type of instruction that, on the one hand, holds up the importance of CLT principles such as authentic communication and student-centeredness, and on the other hand, maintains the value of the occasional and overt study of problematic L2 grammatical forms, which is more reminiscent of non-communicative teaching.

Alternatively, some scholars like Spada (1997) have advocated the use of the term form-focused instruction. Formfocused instruction refers to any pedagogical effort which is used to draw the learners' attention to language form either implicitly or explicitly. This can include the direct teaching of grammar (e.g. through grammatical rules) and/or reactions to the learners' errors (e.g. corrective feedback). The degree of explicitness of form-focused approaches is ranging from an occasional shift of attention to linguistic features to a provision of explicit positive and negative evidence.

As Long (1997) also discussed, Focus on Form should not be confused with form-focused instruction. The latter is an umbrella term which refers to any pedagogical technique, proactive or reactive, implicit or explicit and is used to draw students' attention to language form. It includes Focus on Form procedures, as well as all the activities used for Focus on Forms, such as exercises which are specifically written to teach a grammatical structure proactively. This means that it is the teacher not the learner who decides when is the appropriate moment for learning the new item. Focus on Form, however, refers only to those form-focused activities that arise during, and are embedded in meaning-based lessons; they are not scheduled in advance, as is the case with Focus on FormS, but occur incidentally as a function of the interaction of learners with the subject matter or tasks that constitute the learners' and their teacher's predominant focus.

Thus, according to Long (1991), two kinds of form-focused instruction can be distinguished: Focus-on-FormS and Focus-on-Form. The former involves the pre-selection of specific features based on a linguistic syllabus and the intensive and systematic treatment of those features. As a consequence in Focus on FormS instruction the primary focus of attention is on the form that is being targeted. In contrast, in Focus on Form instruction the primary focus of attention is on meaning. Attention to form arises out of meaning-centered activity derived from the performance of a communicative task.

TBLT in the Iranian EFL Setting

ELT in Iran, like many other countries, has started to opt for task-based language teaching in the last ten years. Nevertheless, the applicability of TBLT in a foreign language setting like Iran with its political, cultural, and social characteristics needs to be investigated thoroughly. The majority of studies on the use of tasks have been conducted in settings where English is a second language (ESL) or in settings such as India, Malaysia, Singapore, and the UAE where there is abundant interaction between the locals and English speaking expatriates and hence the context of language learning very much approaches ESL situations. In other words, TBLT mainly addresses ESL settings where learners' primary objective is having real-life interactions both inside and more importantly outside the classroom. ESL settings also privilege learners with native or near-native teachers together with high amount of exposure in the form of intensive courses. In Iran, however, English class hours during the formal education which starts at the age of 12, when students start their junior high, is only four hours a week and the majority of classes in private language schools at best provide six hours of instruction. Moreover, the chance of using English outside the classroom is very limited and perhaps far less than many other EFL settings. Finally, the immediate objective of a great majority of English learners in Iran is not communication in real life situations but success in some kind of exam. Children and adolescents are headed for the centralized university entrance exam and many adults need to sit for some high-stakes tests such as IELTS or TOEFL for educational or immigration purposes. We, thus, hypothesize that ELT in Iran, at least in its present status, is not fully compatible with TBLT mainly because the major requirements of a successful task-based class are absent in the majority of English classes found in this country. We, further, argue that form-focused teaching can and should play a more significant role in the EFL setting of Iran as the findings of the following study suggest. Hence, prior to the advancement of the study the following research questions were raised to evaluate the use of TBLT in the Iranian EFL setting:

1. Do learners like studying grammar?

2. Is explicit teaching of grammar necessary?

3. Are real-life tasks useful for language learning?

4. Are real-life tasks enough for learning language forms?

5. Should error correction be an essential part of classroom instruction?

6. Are the hours of instruction enough for providing learners with the language exposure they need? 


\section{METHOD}

\section{A. Participants}

The participants of the present study were in two groups:

- The first group included 145 Iranian EFL learners from 15 classes who were randomly selected from among about 900 learners studying at a relatively popular English language school in Tehran. They were all adults with their age ranging from 18 to 40 with different educational backgrounds although the majority (90\%) had at least finished their undergraduate studies. They were studying at three general levels of beginner, intermediate, and advanced.

- The second group embraced 36 Iranian English teachers both male and female who voluntarily participated in this study. They had a minimum of three years of teaching experience and all held at least a bachelor degree. Only $40 \%$ had been studying in an English-related major but all had passed a general proficiency test and had attended the teacher training course of the language school which is a 3-day intensive course touching upon the major trends of language teaching methodology from the Grammar Translation to the more recent approaches in CLT such as content-based and task-based teaching.

\section{B. Instrumentation}

Data gathering in this research was mainly done through a questionnaire with two versions of learners' and teachers'. The questionnaire was developed in Farsi (see Appendix for the English translation) by the researchers based on the one used by Schulz (1996, 1997 cited in Schulz, 2001) which concentrated on extracting learners' and teachers' opinions and attitudes toward teaching grammar and error correction in the US and in Colombia. The first version of our questionnaire had 22 questions which were reduced to 15 after being piloted. The reliability of the abridged version was calculated through Cronbach Alpha $(r=0.79)$. The questionnaire aimed to elicit the agreement or disagreement of both learners and teachers on a Likert-scale (originally on a 1 to 5 scale, but changed to a 1 to 3 scale for computations) about six major issues regarding:

1. learners' attitude towards learning grammar

2. necessity of explicit teaching of grammar,

3. usefulness of real-life tasks for language learning,

4. sufficiency of real-life tasks for learning language forms,

5 . necessity of error correction, and

6. limitation of exposure to classroom hours.

\section{Procedure}

Being descriptive, the procedure of the present study was limited to the preparation of an opinionnaire and its administration to the students and teachers of a number of classes at different proficiency levels in a language school in Tehran.

\section{RESULTS}

The 15 questions of the questionnaires in six sections provided data on the issues addressed in this study. The findings are summarized in the following table:

TABLE 1.

FREQUENCIES AND PERCENTAGES OF LEARNERS AND TEACHERS' RESPONSES

\begin{tabular}{|c|c|c|c|c|c|c|c|c|c|c|c|c|c|}
\hline & & \multicolumn{2}{|l|}{ S 1} & \multicolumn{2}{|l|}{$\mathrm{S} 2$} & \multicolumn{2}{|l|}{ S3 } & \multicolumn{2}{|l|}{$\mathrm{S} 4$} & \multicolumn{2}{|l|}{ S5 } & \multicolumn{2}{|l|}{ S6 } \\
\hline & $\mathrm{N}$ & f & $\%$ & $\mathrm{f}$ & $\%$ & $\mathrm{f}$ & $\%$ & $\mathrm{f}$ & $\%$ & f & $\%$ & $\mathrm{f}$ & $\%$ \\
\hline Learners & 145 & 114 & 79 & 126 & 87 & 123 & 85 & 91 & 63 & 130 & 90 & 127 & 88 \\
\hline Teachers & 36 & 23 & 65 & 33 & 92 & 30 & 85 & 22 & 60 & 31 & 87 & 25 & 65 \\
\hline
\end{tabular}

The following shows the views of the learners:

$1.79 \%$ liked to study grammar.

2. $87 \%$ believed that the explicit teaching of grammar is necessary for better understanding of each lesson and activity.

3. $85 \%$ believed that using real-life tasks are useful for learning to communicate in English.

4. $63 \%$ believed that real-life tasks are NOT enough for learning the language, $23 \%$ were undecided and only $14 \%$ believed that real-life tasks are enough for learning a language.

$5.90 \%$ were in favour of error correction. They preferred to be corrected by the teacher while speaking in class and also thought it was necessary for the teacher to correct all their writings.

6. $88 \%$ agreed that the major obstacle for successful language learning in Iran is the lack of an English speaking environment and the limited hours of instruction in language schools.

Teachers had more or less similar views as extracted from the questionnaire:

1 . $65 \%$ believed that students like to study grammar.

2. $92 \%$ agreed that grammatical explanations are necessary.

3. $85 \%$ thought it is possible to learn English through real-life tasks. 
4. $60 \%$ admitted that real-life tasks are NOT enough for learning the language, $20 \%$ were undecided and $20 \%$ believed that real-life tasks are enough for learning a language.

5. $87 \%$ agreed that all kinds of error correction are useful for students.

6. $65 \%$ regarded the limited hours of instruction and the characteristics of Iranian foreign language setting as the main problems of English language learning.

For a close examination and comparison of the views of the learners and teachers, a series of Chi Square Tests were conducted on the six sections of the questionnaires. Table 2 illustrates the results:

TABLE 2.

X2 VALUES FOR THE SIX SECTIONS OF THE QUESTIONNAIRES

\begin{tabular}{|c|c|c|c|c|c|c|c|c|c|c|c|c|}
\hline & \multicolumn{2}{|c|}{ Q1 } & \multicolumn{2}{|c|}{$\mathrm{Q} 2$} & \multicolumn{2}{|c|}{ Q3 } & \multicolumn{2}{|c|}{$\mathrm{Q} 4$} & \multicolumn{2}{|c|}{ Q5 } & \multicolumn{2}{|c|}{ Q6 } \\
\hline & $\mathrm{df}$ & Q1 & df & Q2 & $\mathrm{df}$ & Q3 & df & Q4 & df & Q5 & $\mathrm{df}$ & Q6 \\
\hline $\mathrm{X}^{2}$ Observed & \multirow{2}{*}{1} & 3.371 & \multirow{2}{*}{1} & 0.60 & \multirow{2}{*}{1} & 0.049 & \multirow{2}{*}{2} & 0.86 & \multirow{2}{*}{1} & 0.364 & \multirow{2}{*}{1} & $7.06^{* * *}$ \\
\hline $\mathrm{X}^{2}$ Critical & & 3.84 & & 3.84 & & 3.84 & & 5.99 & & 3.84 & & 3.84 \\
\hline
\end{tabular}

In the first section, the observed value of X2 (3.37) is only marginally smaller than the critical X2 value of 3.84 . This indicates that learners have a positive attitude towards the study of grammar more than what their teachers assume, Nevertheless, this difference failed to appear significant in this study. In Sections 2 to 5, the obtained values of X2 are far smaller than the critical values (at $1 \mathrm{df}$ except for Section 4 at a df of 2) showing that learners and teachers held more or less the same views. Finally, in Section 6, the observed value of 7.06 being greater than the critical value of $6.64(\mathrm{p}<0.01)$ signifies that teachers adopted a milder position compared to learners towards the problems related to the limited hours of instruction and the characteristics of EFL settings.

\section{DISCUSSION}

Regarding the first and second sections, it can be said that learning grammar is not only disliked by learners, as we might think, but it is also considered to be essential by both learners and teachers in the development of language proficiency. Hence, it can be concluded that it is necessary to also Focus on FormS and teach grammar explicitly both proactively and reactively.

The applicability of real-life tasks which is addressed in the second and third sections is generally viewed as plausible in the sense that except an undecided minority, the majority of both learners and teachers believe that these types of tasks, as the main source of authentic language, are an indispensable if not sufficient part of EFL materials. Furthermore, as expected, teachers in this study were more optimistic about the use of real-life tasks as compared to the learners.

The findings related to the fifth section showed that learners welcome error correction and in fact regard it as one of the major responsibilities of a teacher. The same view is held by teachers. This positive attitude towards error correction or negative evidence usually increases as learners pass early stages of language learning and gain enough self confidence not to be discouraged by frequent corrections of their own or classmates' errors.

Finally, addressing the sixth section, the data showed that, to a greater extent, learners and, to a lesser extent, teachers hold the limited amount of classroom instruction in the special EFL setting of Iran responsible for their inability to learn and teach English effectively.

\section{CONCLUSION}

The present study was an attempt to evaluate the applicability of TBLT in the context of Iran. The empirical data gathered through two questionnaires administered to two groups of Iranian EFL learners and teachers signified that TBLT can become more applicable in the Iranian EFL setting only if it is inclined towards form-focused instruction. Moreover, it could be deduced from the findings that real life tasks in form-focused instruction are necessary to promote communication in Iranian EFL classrooms as they may be the only means of exposure to authentic language, but they are certainly not enough as they are inclined to train inaccurate learners. Furthermore, form-focused instruction as a comprehensive approach would allow for any pedagogical effort to draw the learners' attention to language form either implicitly or explicitly. When dealing with problematic forms, the teacher can respond proactively and adopt a structure-of-the-day kind of approach, or respond reactively through giving corrective feedback to learners' errors. In addition, form-focused instruction emphasizes the necessity of "noticing" to language forms within the context of communicative interactions which is even greater in the Iranian EFL settings where classroom is the only place in which real life activities can be simulated. It is noteworthy that in Iran, TBLT with a form-focused instruction has to deal with only one question: when to Focus on Form and when to Focus on FormS depending on the difficulty of the form, proficiency level of the learners, and the role of the form in performing the task.

To conclude, in EFL settings like Iran where almost the only contact with the target language is in the classroom, the instruction should expose learners to both structured as well as natural language to let them experience how language is used in real life interaction and also internalize the necessary knowledge of linguistic forms to make the interaction possible. 


\section{APPENDIX}

LEARNER QUESTIONNAIRE

\begin{tabular}{|c|c|c|c|c|c|c|}
\hline & & strongly agree & agree & undecided & disagree & strongly disagree \\
\hline 1 & I like the study of grammar & & & & & \\
\hline 2 & $\begin{array}{l}\text { I think it is better if teachers explained the grammatical } \\
\text { point(s) of each lesson and its related activities. }\end{array}$ & & & & & \\
\hline 3 & $\begin{array}{l}\text { Some grammatical points are too difficult to be understood } \\
\text { without the teacher's explanations. }\end{array}$ & & & & & \\
\hline 4 & $\begin{array}{l}\text { The formal study of grammar is essential to eventual mastery } \\
\text { of a foreign language. }\end{array}$ & & & & & \\
\hline 5 & $\begin{array}{l}\text { Teachers' grammatical explanations are necessary for } \\
\text { learning English grammar. }\end{array}$ & & & & & \\
\hline 6 & $\begin{array}{l}\text { In Iran, it is possible to learn English through real-life tasks } \\
\text { (i.e., finding a building on a map, reservation of a room in a } \\
\text { hotel, making stories based on pictures). }\end{array}$ & & & & & \\
\hline 7 & $\begin{array}{l}\text { In Iran, Task-based activities can lead to learning daily-life } \\
\text { language. }\end{array}$ & & & & & \\
\hline 8 & $\begin{array}{l}\text { Task-based activities in our course book are enough for } \\
\text { learning grammar and vocabulary. }\end{array}$ & & & & & \\
\hline 9 & $\begin{array}{l}\text { For doing classroom activities, it is better that the teacher } \\
\text { explain grammatical points and the meaning of the new } \\
\text { words. }\end{array}$ & & & & & \\
\hline 10 & $\begin{array}{l}\text { Fluency is more important than accuracy in speaking. I } \\
\text { dislike it when I am corrected in class. }\end{array}$ & & & & & \\
\hline 11 & $\begin{array}{l}\text { When I make errors in writing, I would like my teacher to } \\
\text { correct them. }\end{array}$ & & & & & \\
\hline 12 & $\begin{array}{l}\text { When I make errors in speaking, I would like my teacher to } \\
\text { correct me. }\end{array}$ & & & & & \\
\hline 13 & $\begin{array}{l}\text { I learn a lot when my teacher corrects the errors made by my } \\
\text { fellow students in class. }\end{array}$ & & & & & \\
\hline 14 & $\begin{array}{l}\text { Learning English is difficult in Iran because of its EFL } \\
\text { setting. }\end{array}$ & & & & & \\
\hline 15 & $\begin{array}{l}\text { The limited hours of classroom instruction in the majority of } \\
\text { language schools makes learning difficult. }\end{array}$ & & & & & \\
\hline
\end{tabular}

TEACHER QUESTIONNAIRE

\begin{tabular}{|c|c|c|c|c|c|c|}
\hline & & strongly agree & agree & undecided & disagree & strongly disagree \\
\hline 1 & Students like the study of grammar & & & & & \\
\hline 2 & $\begin{array}{l}\text { It is necessary for a teacher to explain the grammatical } \\
\text { point }(s) \text { of each lesson and its related activities. }\end{array}$ & & & & & \\
\hline 3 & $\begin{array}{l}\text { Some grammatical points are too difficult to be } \\
\text { understood without the teacher's explanations. }\end{array}$ & & & & & \\
\hline 4 & $\begin{array}{l}\text { The formal study of grammar is essential to eventual } \\
\text { mastery of a foreign language. }\end{array}$ & & & & & \\
\hline 5 & $\begin{array}{l}\text { Teachers' grammatical explanations are necessary for } \\
\text { learning English grammar. }\end{array}$ & & & & & \\
\hline 6 & $\begin{array}{l}\text { In Iran, it is possible to teach English through real-life } \\
\text { tasks (i.e., finding a building on a map, reservation of a } \\
\text { room in a hotel, making stories based on pictures). }\end{array}$ & & & & & \\
\hline 7 & $\begin{array}{l}\text { In Iran, task-based activities can lead to learning daily-life } \\
\text { language. }\end{array}$ & & & & & \\
\hline 8 & $\begin{array}{l}\text { Task-based activities in the course books of the language } \\
\text { school are enough for teaching grammar and vocabulary. }\end{array}$ & & & & & \\
\hline 9 & $\begin{array}{l}\text { For doing classroom activities, it is better that the teacher } \\
\text { explain grammatical points and the meaning of the new } \\
\text { words. }\end{array}$ & & & & & \\
\hline 10 & $\begin{array}{l}\text { Fluency is more important than accuracy in speaking. } \\
\text { Students dislike it when they are corrected in class. }\end{array}$ & & & & & \\
\hline 11 & $\begin{array}{l}\text { Correcting the writing of students is necessary for } \\
\text { improving their grammar and vocabulary knowledge. }\end{array}$ & & & & & \\
\hline 12 & $\begin{array}{l}\text { It is necessary to correct learners when they make errors } \\
\text { in speaking. }\end{array}$ & & & & & \\
\hline 13 & Correcting learners' errors is useful for their peers. & & & & & \\
\hline 14 & $\begin{array}{l}\text { Learning English is difficult in Iran because of its EFL } \\
\text { setting. }\end{array}$ & & & & & \\
\hline 15 & $\begin{array}{l}\text { The limited hours of classroom instruction in the majority } \\
\text { of language schools makes teaching difficult. }\end{array}$ & & & & & \\
\hline
\end{tabular}


[1] Breen, M. (1987). Learner contributions to task design. In C. Candlin \& D. Murphy (Eds.), Language Learning Tasks (pp. 522). Englewood Cliffs, NJ: Prentice-Hall.

[2] Doughty, C., \& Williams, J. (1998). Issues and terminology. In C. Doughty \& J. Williams (Eds.), Focus on form in classroom second language acquisition (1-13). Cambridge: Cambridge University Press.

[3] Foster, P. (1999). Key concepts in ELT: Task-based learning and pedagogy. ELT Journal, 53 (1), 149-156.

[4] Izumi, S. (2002). Focus on form in English language teaching: Integrating meaning and form ASTE, 46. Retrieved November 2 , 2008, from http://www. bun-eido.co.jp/aste46.html

[5] Krashen, S. (1981). Second language acquisition and second language learning. Oxford: Oxford University Press.

[6] Krashen, S. (1985). The input hypothesis. London: Longman.

[7] Krashen, S. (1994). The input hypothesis and its rivals. In N. Ellis (Ed.), Implicit and explicit learning of languages (pp. 45-77). London: Academic Press.

[8] Krashen, S., \& Terrel T. (1983). The Natural Approach: Language acquisition in the classroom. Oxford: Pergamon.

[9] Larsen-Freeman, D. (2000). Techniques and principles in language teaching. Oxford: Oxford University Press.

[10] Long, M. H. (1991). Does second language instruction make a difference? A review of the research. TESOL Quarterly, 17 (3), 359-382.

[11] Long, M. H. (1996). The role of the linguistic environment in second language acquisition. In W. Ritchie \& T. Bhatia (Eds.), Handbook of second language acquisition (pp. 413-468). San Diego: Academic Press.

[12] Long, M. H. (1997). Focus on form in task-based language teaching. Paper Presented at the Fourth Annual McGraw-Hill Satellite Conference. Retrieved March 8, 2009 from http://www.mhhe.com/socscience/foreignlang/conf/task1.htm

[13] Long, M. H., \& Robinson, P. (1998). Focus on form: Theory, research, and practice. In C. Doughty \& J. Williams (Eds.), Focus on form in classroom in second language acquisition (15-42). Cambridge: Cambridge University Press.

[14] Nassaji, H. (1999). Towards integrating form-focused instruction and communicative interaction in the second language classroom: Some pedagogical possibilities. Canadian Modem Language Review, 55 (3). Retrieved November 22, 2008, from http://www.utpjoumals.com/product/cmlr/553/553-Nassaji.html

[15] Nunan, D. (2006). Task-based language teaching in the Asia context: Defining 'task' Asian EFL Journal 8 (3). Retrieved December, 15, 2007 from http:// www.asian-efl-journal.com/september_06_home.php

[16] Poole, A. (2005). Focus on form instruction: Foundations, applications and criticisms. The Reading Matrix, 5(1), 47-56.

[17] Prabhu, N. S. (1987). Second language pedagogy. Oxford: Oxford University Press.

[18] Richards, J. C., \& Schmidt, R. (2002). Longman dictionary of language teaching and applied linguistic. London: Pierson Education.

[19] Schulz, R. A. (2001). Cultural differences in students and teacher perceptions concerning the role of grammar instruction and corrective feedback: US-Colombia'. The Modern Language Journal, 85(2), 244-258.

[20] Skehan, P. (1998). Task-based instruction. In W. Grabe, et al, (Eds.), Annual Review of Applied Linguistics, 18 (pp. 268-286). Foundations of second language teaching. Cambridge: Cambridge University Press.

[21] Spada, N. (1997). Form-focused instruction and second language acquisition: A review of classroom and laboratory research. Language Teaching Journal, 30, 73-87.

[22] Swain, M. (1985). Communicative competence: Some roles of comprehensible input and comprehensible output in its development. In S. Gass \& C. Madden (Eds.), Input in second language acquisition (pp. 235-253). Rowley, Mass.: Newbury House.

[23] Wilkins, D. A. (1976). Notional syllabuses. Oxford: Oxford University Press.

Mojgan Rashtchi was born in Tehran, Iran in 1961. She received her PhD in Applied Linguistics from Islamic Azad University, Science and Research Branch in 1998.

She is currently the Head of Graduate TEFL Department at Islamic Azad University, North Tehran Branch, Iran and has been teaching at undergraduate and graduate levels in the areas of language teaching methodology, research, and language skills. She has published several articles and books on teaching English to children and adults. Her main areas of interest include issues of first language acquisition and exploring teaching techniques to children and adults.

Arshya Keyvanfar was born in Tehran, Iran in 1966. She received her PhD in Applied Linguistics from Islamic Azad University, Science and Research Branch in 1999.

She is currently an assistant professor at Islamic Azad University, North Tehran Branch and has been teaching at undergraduate and graduate levels in the areas of English language teaching methodology, testing, and research. She is particularly interested in TBLT and its application in EFL settings. 